\title{
Application of Intramolecular Heck Reactions to the Preparation of Steroid and Terpene Intermediates Having cis A-B Ring Fusions. Model Studies for the Total Synthesis of Complex Cardenolides.
}

\author{
Sabine Laschat, ${ }^{\text {la }}$ Frank Narjes ${ }^{1 b}$ and Larry E. Overman* \\ Department of Chemistry, University of California \\ Irvine, California USA 92717-2025
}

\begin{abstract}
The cis-fused tricyclic dienone 13 is the major product formed from intramolecular Heck cyclization of the dienyl triflate 12 (Scheme 1). Similarly, the cis-hexahydrophenanthridine 22 is formed in good yield from Heck cyclization of the aryl triflate 21. This latter conversion demonstrates that allylic ether substitution is compatible with intramolecular Heck chemistry and suggests applications of this chemistry in the synthesis of highly oxidized cardenolides.
\end{abstract}

Insertions of aryl- and alkenylpalladium intermediates into tethered alkenes and alkynes (intramolecular Heck reactions) have emerged as a broadly effective method for assembling complex polycyclic molecules. 2,3 The excellent functional group tolerance of palladium-catalyzed reactions and the ability of incramolecularity to overcome the reluctance of substituted alkenes to participate in Heck insertion processes are major reasons for the recent explosive growth in the use of this ring-forming method. Depicted in Fig. 1 arc seven natural products and one natural product congener that have recently been synthesized using intramolecular Heck insertions as the key steps. ${ }^{4}$ For each target molecule the bond formed by the intramolecular Heck reaction is indicated by an arrow. Of particular significance is the utility of intramolecular Heck insertions for constructing congested quaternary carbon centers, ${ }^{5}$ often the most challenging centers in the assembly of complex molecules. This feature is illustrated in Fig 1 in the total syntheses of ( \pm )-6a-epipretazettine, ( $( \pm)$-scopadulcic acid, (-)- and (+)-morphine and $(-)$ - and (+)physostigmine. ${ }^{4 a b c f}$ Also notable is the recent success obtained in several laboratories in effecting asymmetric intramolecular Heck insertions using enantiopure phosphine ligands. ${ }^{6}$ This approach was employed in recent asymmetric syntheses of the Calabar alkaloid (-)-physostigmine and its enantiomer. $4 \mathrm{f}$

$A$ cis $A / B$ ring fusion is a distinctive structural feature of several biologically important classes of steroid natural products. Examples include batrachotoxin $A(1),{ }^{7}$ an extremely toxic amphibian alkaloid 


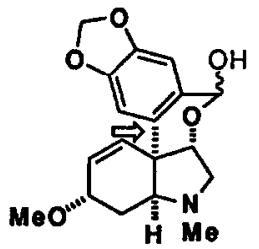

(t)-6a-epipretazettine $e^{4 a}$

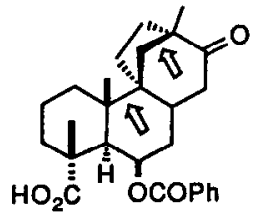

(t)-scopadulcic acid B ${ }^{4 b}$

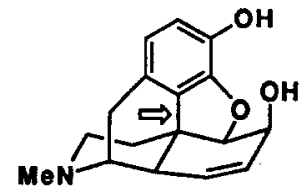

$(-)$ - and (t)-morphine*c

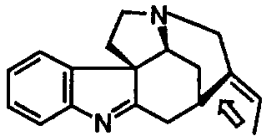

( \pm )-dehydrotubifoline $e^{4 d}$<smiles>C=Cc1cc2c(cc1C(=O)N[C@@H]1C(=C)C=C(O)[C@H](O)[C@@H]1O)OCO2</smiles>

$(+)-$ lycoricidine $e^{40}$<smiles>CC(=O)Oc1ccc2c(c1)C1(C)CCN(C)C1N2C</smiles>

$(-)$-and (+)-physostigmine $e^{4 t}$<smiles>CC[C@]1(O)C(=O)OCc2c1cc1n(c2=O)Cc2cc3ccccc3nc2[C@]1(O)CC</smiles>

(+)-camptothecin ${ }^{40}$

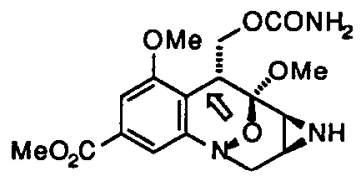

analog of FR $900482^{4 h}$

Fig 1. Polycyclic natural products prepared by intramolecular Heck strategies.

isolated from Phyllobates aurotaenia and the poison-dart frog Dendrobates terribilis, and the complex cardenolide ouabain (2), the active water-soluble extract of the ouabaio tree, which has been long used in East Africa as an arrow poison. ${ }^{8}$ Batrachotoxin $\mathrm{A}$ is an essential tool in mechanistic investigations of voltagedependent sodium channels, $7 \mathrm{~b}$ while ouabain has attracted much recent attention as the long-sought digitalislike factor in plasma. $8 \mathrm{~b}$ In this paper we present our initial findings concerning the use of intramolecular Heck insertions for constructing cis-fused decalin components of polycyclic ring systems. We also report that intramolecular Heck insertions are not undermined by the presence of allylic oxygen substitution, and thus hold considerable promise for the assembly of complex polyhydroxylated cardenolides such as ouabain (2).

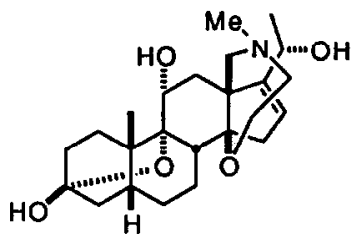

batrachotoxin $A(1)$

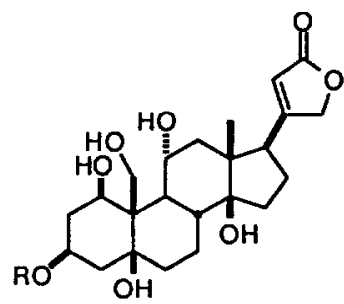

ouabain (2) $\mathrm{R}$<smiles>CC(C)C1C(O)C(O)C(O)C(O)OC1(C)C</smiles>

$\alpha-L-$ hamnoside

ouabagenin (3) $\mathrm{R}=\mathrm{H}$ 


\section{Synthesis Strategy.}

A strategy for assembling a tricyclic precursor of the A-C rings of ouabain is outlined in Fig. 2. The key step in this sequence is the projected intramolecular Heck insertion of the alkenyl aryl triflate 7 to form the cis-fused tricycle 6. This latter intermediate would contain the required angular substituents at $C(5)$ and $C(10)$ of ouabain, as well as alkene functionality in the A ring that would plausibly allow further functionalization to reach 5 and 4 (e.g., $R^{\prime}=O R$ ). Success in the critical conversion of $7 \rightarrow 6$ would depend on the intramolecular Heck reaction occurring faster than potentially competing $\pi$-allyl palladium chemistry arising

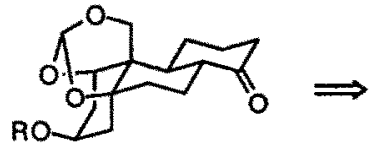

4<smiles>[R]C[C@]12CC[C@](O)(CC(=O)[C@H]3O[C@H]31)[C@@]2(O)CO</smiles>

5<smiles>[R]C[C@]12C=CCC[C@]1(O)CCc1c([R7])cccc12</smiles>

6<smiles>C=CCC1(O)CCCC=C1CO</smiles>

7

Fig. 2. One plan for the synthesis of the $A, B$, and $C$ rings of ouabain.

from the two allylic oxygen substituents present in 7.9 We assumed at the outset that $\pi$-allyl palladium chemistry would be minimized if the oxygen protecting groups were chosen to make $O R$ a poor leaving group. Our expectation that cyclization of 7 would produce the cis tricyclic product 6 followed directly from the established preference for intramolecular Heck insertions to take place with eclipsed (rather than twisted) orientations of the Pd-C $\sigma$ and alkene $\pi$ bonds (Fig. 3).2a,4a The eclipsed mode of insertion of 7 that would lead to 6 is illustrated in insertion conformer 8.

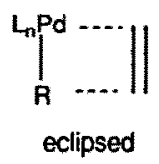

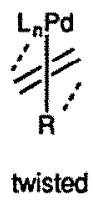<smiles>Oc1ccccc1C1(O)C2CC3CC1CC(C2)C3(O)O</smiles>

8

Fig. 3. Favored eclipsed topography of the insertion step.

\section{RESULTS AND DISCUSSION}

Initial Model Study. We initially examined the issue of stereoselectivity with a cyclization substrate prepared from cyclohexenylethanol 9, a terpenoid intermediate readily available from $\alpha$-ionone (Scheme 1 ). ${ }^{10}$ Alkylation of the derived iodide 10 with lithium reagent $11^{11}$ provided, after hydrolysis, the corresponding 1,3-cyclohexandione, which was converted to triflate 12 by treatment with $\mathrm{NaH}$ and $\mathrm{PhNTf}_{2 .}{ }^{12}$ Intramolecular Heck cyclization of dienyl triflate 12 took place slowly upon treatment with $10-25 \% \mathrm{Pd}\left(\mathrm{Ph}_{3} \mathrm{P}\right)_{4}$ in refluxing MeCN or THF. Cyclization was much faster in the presence of $12 \%$ of a more reactive catalyst prepared from $\mathrm{Pd}(\mathrm{OAc})_{2}$ and slightly less than 2 equiv (per $\mathrm{Pd}$ ) of $\mathrm{Ph} 3 \mathrm{P}$. This latter procedure converted 12 , in essentially 
quantitative yield, into a crystalline 3:1 mixture of the two tricyclic dienones 13 and 14 . That cyclization had occurred to form the cis-fused tricyclic products was rigorously established by single crystal X-ray analysis of the major isomer $13\left(\mathrm{mp} 69^{\circ} \mathrm{C}\right.$ )..$^{13}$ Selective saturation of the isolated double bonds in 13 and 14 could be accomplished with Wilkinson's catalyst and gave a single tricyclic dienone 15.14 This hydrogenation confirms the stereostructure of the minor product 14, and establishes that palladium-catalyzed cyclization of 12 takes place exclusively to form cis-fused tricyclic products.

Scheme 1<smiles>CC1=CCCC(C)(C)C1CCO</smiles>

9
$20 \% \mathrm{Ph}_{3} \mathrm{P}, \mathrm{Et}_{3} \mathrm{~N}$, $(95 \%)$

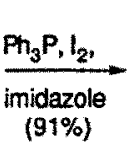

(91\%)

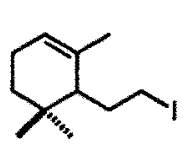

10<smiles>COC1=CCC=C(OC)C1I</smiles>

11

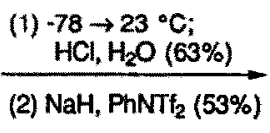

(2) $\mathrm{NaH}, \mathrm{PhNTf}_{2}(53 \%)$<smiles>CC1=CCCC(C)(C)C1CCC1=C(O)CCCC1=O</smiles>

12
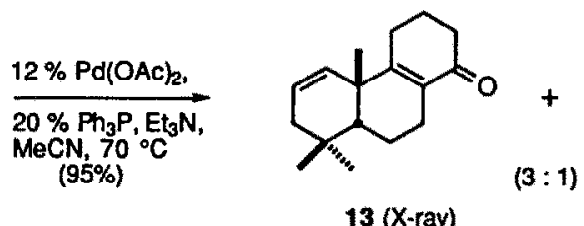<smiles>CC1(C)C=CC[C@]2(C)C3=C(CC[C@H]12)C(=O)CCC3</smiles>

14

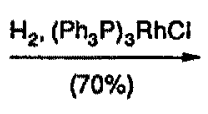

$(70 \%)$<smiles>CC1(C)CCC[C@]2(C)C3=C(CC[C@H]12)C(=O)CCC3</smiles>

15

Synthesis of cis-Octahydrophenanthrenes with the Angular Functionalization of Complex Cardenolides such as Ouabain. An efficient sequence for preparing alkenyl aryl triflate 21, a cyclization substrate containing appropriate oxidation for testing the synthesis plan proposed in Fig. 2, is summarized in Scheme 2. The sequence begins with alkylation of a cyano cuprate intermediate derived from vinyl bromide $16^{15}$ with chloromethyl benzyl ether to provide benzyloxycyclohexenone 17 , which was easily converted to 18 . Suzuki cross coupling of this intermediate with the isopropyldimethylsilyl ether of 2-iodophenol (19) then provided 20.16 The initial step of this sequence, hydroboration of 18 with 9-BBN (9-borabicyclo[3.3.1]nonane), was problematic until it was discovered that the use of 2 equiv of 9-BBN and ultrasound was necessary to achieve clean conversion to the alkyl borane intermediate. ${ }^{17}$ Since some cleavage of the isopropyldimethylsilyl group occurred under the basic palladium-catalyzed cross coupling conditions, the crude reaction mixture was treated with $\mathrm{K}_{2} \mathrm{CO}_{3}$ in $\mathrm{MeOH}$ to fully liberate the phenol moiety and then with $\mathrm{H}_{2} \mathrm{O}_{2}$ to oxidize residual boron compounds. $16 \mathrm{c}$ Conventional conversion ${ }^{12}$ of 20 to the triflate derivative then afforded 21 . When optimized, this sequence provided the alkenyl aryl triflate 21 on gram scales in $62 \%$ overall yield from 18 .

After considerable experimentation, we found that the optimum condition for promoting the desired intramolecular Heck reaction was to treat 21 in $N, N$-dimethylacetamide with $10 \% \mathrm{Pd}(\mathrm{dppb})^{18}$ and $\mathrm{KOAc}$ (10 equiv) at $120^{\circ} \mathrm{C}$, which provided the hexahydrophenanthrenes 22 and 23 in a $20: 1$ ratio and $68 \%$ combined yield. Arene 24, resulting from palladium-catalyzed reduction of 21 , was formed to only a minor extent (5$10 \%)$ under these conditions. Cyclizations employing monodentate phosphine ligands $\left[\mathrm{Pd}\left(\mathrm{Ph}_{3} \mathrm{P}\right)_{4}, \mathrm{Pd}\left(\mathrm{O}_{-}\right.\right.$ tol $\left.{ }_{3} \mathrm{P}\right)_{4}$ or $\mathrm{Pd}\left(\mathrm{Ph}_{3} \mathrm{P}\right)_{2}$ ] at $70-130^{\circ} \mathrm{C}$ in several solvents provided only small amounts of products 22 and 23 and returned considerable starting triflate 21. As observed earlier by Cabri in bimolecular Heck insertions of 
Scheme 2<smiles>BrC1=CCCCC12OCCO2</smiles>

16

$$
\frac{\text { EBuLi; } \mathrm{CuCN} \text {; }}{\mathrm{CICH}_{2} \mathrm{OBn}:}
$$
$(72 \%)$<smiles>O=C1CCCC=C1COCc1ccccc1</smiles>

17
$\frac{\mathrm{CH}_{2}=\mathrm{CHLi}(94 \%)}{\text { TBDMSOTf }(84 \%)}$<smiles>C=CC1(O[Na])CCC=C(COCc2ccccc2)C1(O)C(C)(C)C</smiles>
9-BBN (2 equiv)

ultrasound

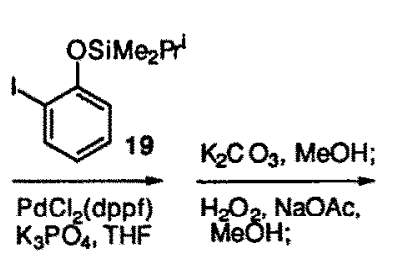<smiles>CCCCCCC1(OCc2ccccc2O)CCCC=C1COCc1ccccc1</smiles>

18 
That alkenes 22 and 23 were double bond regioisomers was established by catalytic hydrogenation of a 1:1.2 mixture of these compounds, which provided the octahydrophenanthridine 26 in quantitative yield. The cis stereochemistry of this intermediate was then rigorously established by conversion to the cyclic acetonide 27 .

\section{CONCLUSION}

This investigation demonstrates that polycyclic molecules containing cis-decalin subunits can be prepared efficiently, with high stereocontrol, by intramolecular Heck insertions. Particularly notable is (a) the high yield obtained in the conversion of $12 \rightarrow 13$ and 14, in spite of the severe 1,3-diaxial Me-Me interaction found in these terpenoid products, and (b) the stability of the two allylic ether oxygens during the cyclization of $21 \rightarrow 22$. These successful cyclizations provide further evidence of the utility of intramolecular Heck reactions in the synthesis of complex, polyfunctional target molecules and specifically suggest applications for the total synthesis of unusual terpenes and steroids.

\section{EXPERIMENTAL SECTION}

(2,6,6-Trimethyl-2-cyclohexenyl)-2-iodoethane (10). Iodine $(230 \mathrm{mg}, 0.91 \mathrm{mmol}$ ) was added in small portions at $0^{\circ} \mathrm{C}$ to a solution of alcohol $910(107 \mathrm{mg}, 0.64 \mathrm{mmol}), \mathrm{Ph} 3 \mathrm{P}(217 \mathrm{mg}, 0.83 \mathrm{mmol})$, imidazole $(59 \mathrm{mg}, 0.87 \mathrm{mmol})$, acetonitrile $(6 \mathrm{~mL})$ and ether $(10 \mathrm{~mL})$. After stirring for $1 \mathrm{~h}$ at $0{ }^{\circ} \mathrm{C}$, the brown reaction mixture was diluted with ether $\left(100 \mathrm{~mL}\right.$ ), washed (saturated aqueous $\mathrm{Na}_{2} \mathrm{~S}_{2} \mathrm{O}_{3}$, saturated aqueous $\mathrm{CuSO}_{4}$, $\mathrm{H}_{2} \mathrm{O}$ ), dried $\left(\mathrm{MgSO}_{4}\right)$ and concentrated. The residue was purified on silica gel (2:1 pentane-ether) to yield $161 \mathrm{mg}(91 \%)$ of 10 as a colorless oil (95\% pure by GLC analysis): $\left.1 \mathrm{H} \mathrm{NMR} \mathrm{(500} \mathrm{MHz}, \mathrm{CDCl}_{3}\right) \delta 0.88(\mathrm{~s}$, $3 \mathrm{H}), 0.92(\mathrm{~s}, 3 \mathrm{H}), 1.15-1.20(\mathrm{~m}, 1 \mathrm{H}), 1.34-1.39(\mathrm{~m}, 1 \mathrm{H}), 1.43-1.46(\mathrm{~m}, 1 \mathrm{H}), 1.70(\mathrm{~d}, \mathrm{~J}=1.4 \mathrm{~Hz}, 3 \mathrm{H}), 1.87-$ $1.97(\mathrm{~m}, 3 \mathrm{H}), 2.03-2.10(\mathrm{~m}, 1 \mathrm{H}), 3.23(\mathrm{t}, \mathrm{J}=8.3 \mathrm{~Hz}, 2 \mathrm{H}), 5.33(\mathrm{bs}, 1 \mathrm{H}) ; 13 \mathrm{C} \mathrm{NMR}(75 \mathrm{MHz}, \mathrm{CDCl}) \delta$ 7.0, 22.9, 23.4, 27.2, 27.5, 31.7, 32.4, 36.3, 51.0, 121.1, 135.0; IR (film) 3044, 2972, 2924, 2852, 1456, 1448, $1374,1350,1218,1170 \mathrm{~cm}^{-1}$; MS(CI) m/z 279.0578 (279.0612 calcd. for $\left.\mathrm{C}_{11} \mathrm{H}_{20} \mathrm{I}, \mathrm{MH}\right), 278,222,205,177$, $162,151,149,123,112,109,95,81$.

2-(2-(2,6,6-Trimethyl-2-cyclohexenyl)ethyl)-3-(trifluoromethylsulfonyl)oxy-cyclohexenone (12). Following the general procedure of Piers, ${ }^{11}$ a solution of 1,5-dimethoxy-1,4-cyclohexadiene (320 mg, 2.3 $\mathrm{mmol})$ and dry THF ( $2.3 \mathrm{~mL}$ ) was added dropwise to a solution of tert-BuLi (1.5 mL, $2.5 \mathrm{mmol}$ of a $1.68 \mathrm{M}$ solution in pentane) and dry THF $(13 \mathrm{~mL})$ at $-78^{\circ} \mathrm{C}$. The resulting yellow solution was stirred for $1 \mathrm{~h}$ at $-78^{\circ}$ C, HMPA $(530 \mu \mathrm{L}, 3.05 \mathrm{mmol})$ was added and the resulting orange-red solution was stirred for $15 \mathrm{~min}$ at -78 ${ }^{\circ} \mathrm{C}$. A solution of iodide $10(707 \mathrm{mg}, 2.54 \mathrm{mmol})$ and dry THF $(2.3 \mathrm{~mL})$ then was added dropwise at $-78{ }^{\circ} \mathrm{C}$ and after $15 \mathrm{~min}$ the reaction was allowed to warm to $23^{\circ} \mathrm{C}$. After $2 \mathrm{~h}$, the mixture was quenched with brine $(25 \mathrm{~mL})$ and extracted with pentane $(3 \times 25 \mathrm{~mL})$. The combined pentane layers were washed (brine), dried $\left(\mathrm{MgSO}_{4}\right)$ and concentrated to yield $709 \mathrm{mg}(\sim 100 \%)$ of the alkylation product as a pale yellow oil, which was used immediately without further purification: $\mathrm{MS}(\mathrm{EI}) \mathrm{m} / \mathrm{z} 290.2242$ (290.2246 calcd. for $\mathrm{C}_{19} \mathrm{H}_{30} \mathrm{O}_{2}, \mathrm{M}$ ).

This crude material was purged with Ar, dissolved in acetone $(11 \mathrm{~mL}$, previously purged for $15 \mathrm{~min}$ with $\mathrm{Ar})$, then $1 \mathrm{~N} \mathrm{HCl}(3.5 \mathrm{~mL}, 3.50 \mathrm{mmol}$, previously purged for $15 \mathrm{~min}$ with $\mathrm{Ar}$ ) was added with vigorous stirring. After $4 \mathrm{~h}$, the reaction was concentrated and the residue partitioned between brine $(50 \mathrm{~mL})$ and 
$\mathrm{CH}_{2} \mathrm{Cl}_{2}(4 \times 50 \mathrm{~mL})$. The combined organic layers were washed (brine), dried $\left(\mathrm{MgSO}_{4}\right)$ and concentrated. Flash chromatography on silica gel $(3: 1 \rightarrow 1: 1$ hexane-EtOAc) yielded $380 \mathrm{mg}(63 \%)$ of 2-(2-(2,6,6-trimethyl2-cyclohexenyl)ethyl)-1,3-cyclohexadione as a colorless, sticky solid: $\mathrm{mp} 148-150^{\circ} \mathrm{C} ; \mathrm{MS}(\mathrm{EI}) \mathrm{m} / \mathrm{z} 262.1927$ (262.1933 calcd. for $\mathrm{C}_{17} \mathrm{H}_{27} \mathrm{O}_{2}, \mathrm{M}$ ).

A solution of a portion of this dione sample $(340 \mathrm{mg}, 1.30 \mathrm{mmol})$ and dry THF $(2.8 \mathrm{~mL})$ was added dropwise at $0^{\circ} \mathrm{C}$ to a suspension of $\mathrm{NaH}(55 \mathrm{mg}$ of a $60 \%$ dispersion in mineral oil, $1.4 \mathrm{mmol}$ ) and dry THF $(1.4 \mathrm{~mL})$. After $\mathrm{H}_{2}$-evolution ceased $(-10 \mathrm{~min})$, the mixture was stirred for $30 \mathrm{~min}$ at $23^{\circ} \mathrm{C}$ and then cooled to $0^{\circ} \mathrm{C}$. A solution of $N$-phenyl-trifluoromethanesulfonylimide $(509 \mathrm{mg}, 1.42 \mathrm{mmol}$ ) and dry THF (1.4 mL) then was added dropwise and the resulting mixture was warmed to $23^{\circ} \mathrm{C}$ and then to $60^{\circ} \mathrm{C}$. After stirring for $16 \mathrm{~h}$ at $60^{\circ} \mathrm{C}$, the reaction was diluted with ether $\left(50 \mathrm{~mL}\right.$ ), washed (saturated aqueous $\mathrm{NaHCO}_{3}$ ), dried $\left(\mathrm{K}_{2} \mathrm{CO}_{3}\right)$ and concentrated. Flash chromatography on silica gel (10:1 hexane-EtOAc) yielded $434 \mathrm{mg}(85 \%)$

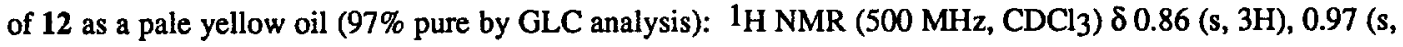
$3 \mathrm{H}), 1.11-1.14(\mathrm{~m}, 1 \mathrm{H}), 1.31-1.36(\mathrm{~m}, 1 \mathrm{H}), 1.37-1.47(\mathrm{~m}, 3 \mathrm{H}), 1.70(\mathrm{~s}, 3 \mathrm{H}), 1.93$ (broad s, 2H), $2.03-2.08$ $(\mathrm{m}, 2 \mathrm{H}), 2.36-2.40(\mathrm{~m}, 2 \mathrm{H}), 2.45(\mathrm{t}, \mathrm{J}=6.6 \mathrm{~Hz}, 2 \mathrm{H}), 2.74(\mathrm{t}, \mathrm{J}=6.2 \mathrm{~Hz}, 2 \mathrm{H}), 5.29(\mathrm{bs}, 1 \mathrm{H}) ; 13 \mathrm{C}$ NMR (125 $\left.\mathrm{MHz}_{2} \mathrm{CDCl}_{3}\right) \delta 20.6,22.9,23.1,24.4,27.2,27.4,28.5,29.5,31.4,32.4,36.9,49.3,118.2(\mathrm{q}, \mathrm{J}=319 \mathrm{~Hz}$ ), 120.3, 132.6, 136.0, 161.6, 197.3; IR (film) 2959, 2937, 2925, 2918, 2874, 1681, 1660, 1420, 1347, 1243, $1215,1140,1039,1031,918,796,628 \mathrm{~cm}^{-1}$; $\mathrm{MS}(\mathrm{Cl}) \mathrm{m} / 2395.1483$ (395.1504 calcd. for $\mathrm{C}_{18} \mathrm{H}_{26} \mathrm{~F}_{3} \mathrm{O}_{4} \mathrm{~S}$, $\mathrm{MH}), 313,261,245,205,181,137,125,109,95$.

Pd(0)-Catalyzed Cyclization of Vinyltriflate 12 to Form Tricyclic Dienones 13 and 14. A solution of $12(100 \mathrm{mg}, 0.25 \mathrm{mmol}), \mathrm{Pd}(\mathrm{OAc})_{2}(5.7 \mathrm{mg}, 0.03 \mathrm{mmol}), \mathrm{PPh}_{3}$ (13.1 mg, $\left.0.05 \mathrm{mmol}\right), \mathrm{Et} 3 \mathrm{~N}(71 \mu \mathrm{L}, 0.51$ $\mathrm{mmol}$ ) and dry acetonitrile $(7.6 \mathrm{~mL})$ was heated at $70^{\circ} \mathrm{C}$ for $6 \mathrm{~h}$. The reaction mixture then was adsorbed onto Florisil and extracted with ether. Concentration of the ether extract and purification of the residue by flash chromatography on silica gel (10:1 hexane-EtOAc) yielded $62 \mathrm{mg}(\sim 100 \%)$ of a pale yellow oil (a 77:23 mixture of 13 and 14 by GLC analysis), which crystallized overnight. These isomers could be separated by preparative HPLC (silica gel, 20:1 hexane-EtOAc). Major isomer 13: colorless plates, mp $69^{\circ} \mathrm{C}$ (hexaneEtOAc); 1H NMR (500 MHz, $\left.\mathrm{CDCl}_{3}\right) \delta 0.78(\mathrm{~s}, 3 \mathrm{H}), 1.00(\mathrm{~s}, 3 \mathrm{H}), 1.23(\mathrm{~s}, 3 \mathrm{H}), 1.49$ (dd, J = 4.9, 3.6 Hz, $1 \mathrm{H}), 1.65(\mathrm{dd}, \mathrm{J}=17.4,5.1 \mathrm{~Hz}, 1 \mathrm{H}), 1.84-2.00(\mathrm{~m}, 5 \mathrm{H}), 2.24-2.45(\mathrm{~m}, 6 \mathrm{H}), 5.65$ (ddd, J = 10.3, 5.2, $2.1 \mathrm{~Hz}$, $1 \mathrm{H}), 5.70(\mathrm{~d}, \mathrm{~J}=10.3 \mathrm{~Hz}, 1 \mathrm{H}) ; 13 \mathrm{C} \mathrm{NMR}\left(125 \mathrm{MHz}, \mathrm{CDCl}_{3}\right) \delta 18.2,20.4,22.8,23.5,26.6,29.5,29.9,32.8$, 37.7, 40.1, 42.9, 47.5, 125.9, 131.4, 131.9, 162.0, 199.4; IR (film) 3020, 2950, 2938, 2897, 2867, 2833, 1665, $1622,1464,1456,1436,1378,1366,1325,1296,1197,1188,1131,725 \mathrm{~cm}^{-1}$; MS (EI) m/z 244.1823 (244.1827 calcd. for $\left.\mathrm{C}_{17} \mathrm{H}_{24} \mathrm{O}, \mathrm{M}, 100 \%\right), 229$ (85\%), 188 (46\%), 162 (62\%), 147 (36\%), 134 (41\%), 119 (16\%), 105 (24\%). Minor isomer 14: colorless plates; mp $105^{\circ} \mathrm{C} ;{ }^{1} \mathrm{H}$ NMR (500 $\mathrm{MHz}, \mathrm{CDCl} 3$, partial) $\delta$ $0.92(\mathrm{~s}, 3 \mathrm{H}), 1.00(\mathrm{~s}, 3 \mathrm{H}), 1.18(\mathrm{~s}, 3 \mathrm{H}), 5.38(\mathrm{~d}, \mathrm{~J}=10.3 \mathrm{~Hz}, 1 \mathrm{H}), 5.46(\mathrm{ddd}, \mathrm{J}=10.3,5.2,3.1 \mathrm{~Hz}, 1 \mathrm{H}) ; 13 \mathrm{C}$ NMR (125 MHz, CDCl3, partial) $\delta 20.9,23.0,25.9,26.5,29.0,31.8,37.6,39.2,47.6,120.0,130.9,138.0$, $163.5,199.8$.

Hydrogenation of 13 and 14 to Form Tricyclic Enone 15. A solution of a $\sim 2: 1$ mixture of enones 13 and 14 (24 mg, $0.10 \mathrm{mmol})$, dry benzene $(5 \mathrm{~mL})$ and $\left(\mathrm{Ph}_{3} \mathrm{P}\right)_{3} \mathrm{RhCl}(15 \mathrm{mg}, 0.02 \mathrm{mmol})$ was shaken in a Parrmedium pressure hydrogenation apparatus at $50 \mathrm{psi}$ for $9 \mathrm{~h}$ at $23^{\circ} \mathrm{C}$. The reaction mixture then was adsorbed 
onto Florisil and was extracted with ether. Concentration of the ether extract and purification of the residue by flash chromatography (10:1 hexane-EtOAc) yielded $17 \mathrm{mg} \mathrm{(70 \% )} \mathrm{of} 15$ as a colorless oil (97\% pure by GLC), which crystallized overnight: $\mathrm{mp} 60-61^{\circ} \mathrm{C}$; ${ }_{1}^{1} \mathrm{H} \mathrm{NMR}(500 \mathrm{MHz}, \mathrm{CDCl} 3) \delta 0.78(\mathrm{~s}, 3 \mathrm{H}), 0.95(\mathrm{~s}, 3 \mathrm{H}), 1.09$ (s, $3 \mathrm{H}), 1.15-1.33(\mathrm{~m}, 4 \mathrm{H}), 1.42-1.48(\mathrm{~m}, 1 \mathrm{H}), 1.86-1.92(\mathrm{~m}, 2 \mathrm{H}), 1.96-2.00(\mathrm{~m}, 2 \mathrm{H}), 2.05-2.07(\mathrm{~m}, 2 \mathrm{H})$, 2.12 - $2.19(\mathrm{~m}, 1 \mathrm{H}), 2.31$ - $2.42(\mathrm{~m}, 5 \mathrm{H}), ; 13 \mathrm{C} \mathrm{NMR}(125 \mathrm{MHz}, \mathrm{CDCl} 3) \delta 17.3,20.4,20.7,22.7,23.2,25.8$, $31.4,32.5,34.6,37.1,37.5,39.0,42.6,49.2,132.6,163.1,199.5 ; \mathrm{MS}(\mathrm{EI}) \mathrm{m} / \mathrm{z} 246.1980$ (246.1984 calcd. for $\left.\mathrm{C}_{17} \mathrm{H}_{26} \mathrm{O}, \mathrm{M}, 48 \%\right), 247(100 \%), 231$ (11\%).

2-(Benzyloxymethyl)-2-cyclohexenone (17). A solution of tert-BuLi $(31.5 \mathrm{~mL}, 53.6 \mathrm{mmol}, 1.7 \mathrm{M}$ in pentane) was added dropwise to a cold $\left(-78^{\circ} \mathrm{C}\right)$ solution of bromoketal $16(5.34 \mathrm{~g}, 24.4 \mathrm{mmol})$ and THF (60 $\mathrm{mL}$ ). After $30 \mathrm{~min}$ the reaction was warmed to $-40^{\circ} \mathrm{C}$, maintained at that temperature for $15 \mathrm{~min}$ and then recooled to $-78^{\circ} \mathrm{C}$. Solid $\mathrm{CuCN}(1.14 \mathrm{~g}, 12.7 \mathrm{mmol}$, dried azeotropically $2 \mathrm{x}$ with $2 \mathrm{~mL}$ of toluene) was added in one portion, and the reaction was warmed to $-40^{\circ} \mathrm{C}$ and stirred until the $\mathrm{CuCN}$ was completely dissolved $(\sim 10 \mathrm{~min})$. After recooling to $-78^{\circ} \mathrm{C}$, a solution of chloromethyl benzyl ether $(7.45 \mathrm{~mL}, 53.6 \mathrm{mmol}$, freshly distilled and filtered through basic alumina before use) and THF ( $5 \mathrm{~mL}$ ) was added dropwise and the reaction was allowed to warm to $0{ }^{\circ} \mathrm{C}$. Water $(10 \mathrm{~mL})$ and saturated aqueous solution of $\mathrm{NH}_{4} \mathrm{Cl}(4 \mathrm{~mL})$ were added, and the resulting mixture was stirred vigorously until TLC (3:1 hexane-EtOAc) confirmed that deketalization was complete. The organic phase then was washed $\left(2 \mathrm{~N} \mathrm{NH} 4 \mathrm{OH}, \mathrm{H}_{2} \mathrm{O}\right.$, brine), dried $\left(\mathrm{MgSO}_{4}\right)$, filtered and concentrated, and the residue purified by flash chromatography (8:1 hexane-EtOAc) to give $3.8 \mathrm{~g} \mathrm{(72 \% )} \mathrm{of} 17$ as a light yellow oil: ${ }^{1} \mathrm{H} \mathrm{NMR}\left(300 \mathrm{MHz}, \mathrm{CDCl}_{3}\right) \delta 1.98(\mathrm{~m}, 2 \mathrm{H}), 2.34-2.48(\mathrm{~m}, 4 \mathrm{H}), 4.19(\mathrm{~d}, \mathrm{~J}=1.8 \mathrm{~Hz}, 1 \mathrm{H})$, $4.20(\mathrm{~d}, \mathrm{~J}=1.8 \mathrm{~Hz}, 1 \mathrm{H}), 4.51(\mathrm{~s}, 2 \mathrm{H}), 7.05(\mathrm{~m}, 1 \mathrm{H}), 7.22-7.40(\mathrm{~m}, 5 \mathrm{H}) ;{ }^{13} \mathrm{C} \mathrm{NMR}(75 \mathrm{MHz}, \mathrm{CDCl} 3) \delta 22.7$, 25.6, 38.1, 66.8, 72.9, 127.5, 127.6, 128.3, 136.3, 138.1, 146.4, 198.5; IR (film) 3087, 3063, 3031, 1674, 1497, $1083,1070,737,689 \mathrm{~cm}^{-1} ; \mathrm{MS}(\mathrm{Cl}) \mathrm{m} / \mathrm{z} 217.1234\left(217.1228\right.$ calcd for $\left.\mathrm{C}_{14} \mathrm{H}_{17} \mathrm{O}_{2}, \mathrm{MH}\right), 125,111,110$.

2-(Benzyloxymethyl)-1-tert-butyldimethylsiloxy-1-ethenyl-2-cyclohexene (18). To a cold $\left(-78{ }^{\circ} \mathrm{C}\right)$ THF solution $(25 \mathrm{~mL})$ of ketone $17(1.0 \mathrm{~g}, 4.6 \mathrm{mmol})$ was added slowly a solution of vinyllithium [prepared from tetravinyltin $(2.44 \mathrm{~g}, 10.7 \mathrm{mmol})$ and $n-B u L i(40.7 \mathrm{mmol})]$ and THF $(20 \mathrm{~mL})]$. After $10 \mathrm{~min}$ the reaction was quenched with saturated aqueous $\mathrm{NH}_{4} \mathrm{Cl}$, extracted with EtOAc and the organic phase was washed $\left(\mathrm{H}_{2} \mathrm{O}\right.$, brine) and dried ( $\left.\mathrm{MgSO}_{4}\right)$. After concentration the residue was purified by flash chromatography (9:1 hexaneEtOAc) to give $1.05 \mathrm{~g}(94 \%)$ of the corresponding tertiary alcohol as a colorless oil: ${ }^{1} \mathrm{H} \mathrm{NMR} \mathrm{(300} \mathrm{MHz,}$ $\left.\mathrm{CDCl}_{3}\right) \delta 1.55-1.90(\mathrm{~m}, 4 \mathrm{H}), 2.04(\mathrm{~m}, 1 \mathrm{H}), 2.17(\mathrm{~m}, 1 \mathrm{H}), 3.56(\mathrm{~s}, 1 \mathrm{H}), 3.83(\mathrm{~d}, \mathrm{~J}=10.5 \mathrm{~Hz}, 1 \mathrm{H}), 4.22(\mathrm{dt}, \mathrm{J}=$ $1.1,10.5 \mathrm{~Hz}, 1 \mathrm{H}), 4.46(\mathrm{~d}, \mathrm{~J}=11.6 \mathrm{~Hz}, 1 \mathrm{H}), 4.50(\mathrm{~d}, \mathrm{~J}=11.6 \mathrm{~Hz}, 1 \mathrm{H}), 5.14(\mathrm{dd}, \mathrm{J}=1.6,10.6 \mathrm{~Hz}, 1 \mathrm{H}), 5.35$ $(\mathrm{dd}, \mathrm{J}=1.7,17.0 \mathrm{~Hz}, 1 \mathrm{H}), 5.91$ (dd, $\mathrm{J}=10.6,17.0 \mathrm{~Hz}, 1 \mathrm{H}), 5.92(\mathrm{bs}, 1 \mathrm{H}), 7.21-7.48(\mathrm{~m}, 5 \mathrm{H})$.

To a cold $\left(-78^{\circ} \mathrm{C}\right)$ solution of 2,6 -lutidine $(3.34 \mathrm{~mL}, 28.7 \mathrm{mmol})$, tert-butyldimethylsilyl trifluoromethanesulfonate $(4.54 \mathrm{~g}, 17.2 \mathrm{mmol})$ and THF $(30 \mathrm{~mL})$ was slowly added a THF solution ( $8 \mathrm{~mL})$ of a comparable sample of this alcohol $(1.4 \mathrm{~g}, 5.73 \mathrm{mmol})$. This solution was allowed to warm to $23^{\circ} \mathrm{C}$, hexane $\left(100 \mathrm{~mL}\right.$ ) was added and the resulting mixture was washed ( $1 \mathrm{~N} \mathrm{HCl}$, saturated aqueous $\mathrm{NH}_{4} \mathrm{Cl}, \mathrm{H}_{2} \mathrm{O}$, brine). After drying (MgSO 4$)$, filtration and concentration gave an oil that was purified by flash chromatography (50:1 hexane-EtOAc containing $0.2 \%$ NEt3) to yield $1.72 \mathrm{~g}(84 \%)$ of 18 as a colorless oil: ${ }^{1} \mathrm{H}$ NMR (500 $\mathrm{MHz}, \mathrm{CDCl} 3) \delta 0.07(\mathrm{~s}, 3 \mathrm{H}), 0.09(\mathrm{~s}, 3 \mathrm{H}), 0.86(\mathrm{~s}, 9 \mathrm{H}), 1.68(\mathrm{~m}, 1 \mathrm{H}), 1.72(\mathrm{~m}, 1 \mathrm{H}), 1.85(\mathrm{~m}, 2 \mathrm{H}), 2.11(\mathrm{~m}$, 
$2 \mathrm{H}), 3.98(\mathrm{dd}, \mathrm{J}=1.7,13.4 \mathrm{~Hz}, 1 \mathrm{H}), 4.07(\mathrm{dd}, \mathrm{J}=1.9,13.4 \mathrm{~Hz}, 1 \mathrm{H}), 4.48(\mathrm{~d}, \mathrm{~J}=11.9 \mathrm{~Hz}, 1 \mathrm{H}), 4.53(\mathrm{~d}, \mathrm{~J}=$ $11.9 \mathrm{~Hz}, 1 \mathrm{H}), 5.06(\mathrm{dd}, \mathrm{J}=1.5,10.5 \mathrm{~Hz}, 1 \mathrm{H}), 5.19(\mathrm{dd}, \mathrm{J}=1.7,17.2 \mathrm{~Hz}, 1 \mathrm{H}), 5.92(\mathrm{dd}, \mathrm{J}=10.5,17.2 \mathrm{~Hz}, 1 \mathrm{H}$ ), 5.93 (bs, $1 \mathrm{H}), 7.22-7.41(\mathrm{~m}, 5 \mathrm{H}) ;{ }^{13} \mathrm{C} \mathrm{NMR}\left(125 \mathrm{MHz}, \mathrm{CDCl}_{3}\right) \delta-2.4,-1.9,18.5,19.6,24.8,25.9,37.5,69.0$, $72.5,76.2,113.0,124.2,127.4,127.6,128.2,137.5,138.7,143.1$; IR (film) 3089, 3066, 3031, 1253, 1123, $1091,1074,1040,913,860,836,773 \mathrm{~cm}^{-1}$; MS (CI) m/z 359.2401 (359.2409 calcd for $\mathrm{C}_{22} \mathrm{H}_{35} \mathrm{O}_{2} \mathrm{Si}, \mathrm{MH}$ ), 357, 302, 301, 251, 227, 209, 199, 183, 133, 121; Anal. Calcd for $\mathrm{C}_{22} \mathrm{H}_{34} \mathrm{O}_{2} \mathrm{Si}$ : C. 73.69; H, 9.56; Found: C, $73.65 ; \mathrm{H}, 9.51$.

\section{2-[(2-(Benzyloxymethyl)-1-(tert-butyldimethylsiloxy-2-cyclohexen-1-yl)ethyl]phenyl}

triffuoromethanesulfonate (21). A solution of alkene $18(308 \mathrm{mg}, 0.856 \mathrm{mmol})$ and THF $(0.5 \mathrm{~mL})$ was added to a cold $\left(0^{\circ} \mathrm{C}\right) \mathrm{THF}$ solution of $9-\mathrm{BBN}(3.44 \mathrm{~mL}, 1.72 \mathrm{mmol}, 0.5 \mathrm{M})$. The resulting solution was stirred at $23{ }^{\circ} \mathrm{C}$ for $10 \mathrm{~min}$ and then sonicated (micro tip, maximum output of a vibra cell sonicator) for 100 min. After cooling to $0{ }^{\circ} \mathrm{C}$, a degassed aqueous solution of $\mathrm{K}_{3} \mathrm{PO}_{4}(0.57 \mathrm{~mL}, 1.7 \mathrm{mmol}, 3 \mathrm{M})$ was added, the resulting mixture was stirred at $23^{\circ} \mathrm{C}$ for $10 \mathrm{~min}$ (gas evolution was observed) and then $\mathrm{PdCl}_{2}(\mathrm{dppf})(63 \mathrm{mg}$, $0.086 \mathrm{mmol}$ ) and a THF solution ( $1 \mathrm{~mL}$ ) of aryl iodide $19(302 \mathrm{mg}, 0.942 \mathrm{mmol}$ ) were added (the solution turned deep red). After stirring for $6.5 \mathrm{~h}$ at $50^{\circ} \mathrm{C}$, the resulting light brown mixture was diluted with EtOAc, washed $\left(\mathrm{NH}_{4} \mathrm{Cl}, \mathrm{H}_{2} \mathrm{O}\right.$, brine), and dried $\left(\mathrm{MgSO}_{4}\right)$. Concentration gave a brown oil that was dissolved in MeOH-THF ( $5 \mathrm{~mL}, 4: 1)$, solid $\mathrm{K}_{2} \mathrm{CO}_{3}(180 \mathrm{mg}, 1.3 \mathrm{mmol})$ was added and the resulting mixture was stirred at $23^{\circ} \mathrm{C}$ for $2 \mathrm{~h}$. Extraction with $\mathrm{CH}_{2} \mathrm{Cl}_{2}$, washing (brine), drying $\left(\mathrm{MgSO}_{4}\right)$ and concentration gave a brown oil, which was dissolved in THF $(2 \mathrm{~mL})$. An aqueous solution of $\mathrm{NaOAc}(1 \mathrm{~mL}, 3 \mathrm{M})$ was added followed by careful addition of $30 \% \mathrm{H}_{2} \mathrm{O}_{2}(1 \mathrm{~mL})$ at $0^{\circ} \mathrm{C}$ and finally $\mathrm{EtOH}$ was added dropwise until the mixture became homogeneous. After stirring for $1.5 \mathrm{~h}$ at $23^{\circ} \mathrm{C}$, this solution was concentrated, the residue was dissolved in ErOAc and washed $\left(2 \mathrm{~N} \mathrm{NH} 4 \mathrm{Cl}, \mathrm{H}_{2} \mathrm{O}\right.$, brine), dried $\left(\mathrm{MgSO}_{4}\right)$ and concentrated to give a dark oil, which was chromatographed on silica gel (20:1 hexane-EtOAc) to give $57 \mathrm{mg}(-15 \%)$ of 18 and $253 \mathrm{mg}(65 \%)$ of 20 as a colorless oil (purity $>90 \%$ by ${ }^{1} \mathrm{H}-\mathrm{NMR}$ and $\mathrm{GC}$ analysis), which was directly employed in the next step:

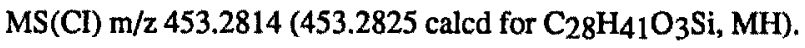

A solution of phenol $20(253 \mathrm{mg}, 0.56 \mathrm{mmol})$ and THF $(2.8 \mathrm{~mL})$ was treated with $\mathrm{NaH}(16 \mathrm{mg}, 0.67$ $\mathrm{mmol}$ ) at $0{ }^{\circ} \mathrm{C}$ and the resulting mixture was stirred at $23^{\circ} \mathrm{C}$ until all the $\mathrm{NaH}$ had reacted $(\sim 10 \mathrm{~min})$. Solid $\mathrm{N}$ phenyl-trifluoromethanesulfonylimide $(226 \mathrm{mg}, 0.67 \mathrm{mmol})$ was added portionwise at $0^{\circ} \mathrm{C}$, the reaction was stirred for $1 \mathrm{~h}$ at $23^{\circ} \mathrm{C}$, EtOAc was added and the resulting solution was washed (brine), dried $\left(\mathrm{MgSO}_{4}\right)$ and concentrated. Purification of the residue by flash chromatography on silica gel (50:1 hexane-EtOAc) gave 310 $\mathrm{mg}$ (62\% from 18) of triflate 21 as a colorless oil: ${ }^{1} \mathrm{H} \mathrm{NMR}(500 \mathrm{MHz}, \mathrm{CDCl} 3) \delta 0.04(\mathrm{~s}, 3 \mathrm{H}), 0.11(\mathrm{~s}, 3 \mathrm{H})$, $0.92(\mathrm{~s}, 9 \mathrm{H}), 1.69(\mathrm{~m}, 1 \mathrm{H}), 1.78(\mathrm{~m}, 2 \mathrm{H}), 1.92(\mathrm{dt}, \mathrm{J}=5.1,12.5 \mathrm{~Hz}, 1 \mathrm{H}), 1.98-2.16(\mathrm{~m}, 4 \mathrm{H}), 2.70-2.84(\mathrm{~m}, 2 \mathrm{H})$, 3.97 (dd, $\mathrm{J}=1.2,12.1 \mathrm{~Hz}, 1 \mathrm{H}), 4.23(\mathrm{dd}, \mathrm{J}=1.1,12.1 \mathrm{~Hz}, 1 \mathrm{H}), 4.50(\mathrm{~d}, \mathrm{~J}=11.7 \mathrm{~Hz}, 1 \mathrm{H}), 4.57(\mathrm{~d}, \mathrm{~J}=11.7 \mathrm{~Hz}$, $1 \mathrm{H}), 5.91(\mathrm{t}, \mathrm{J}=3.7 \mathrm{~Hz}, 1 \mathrm{H}), 7.21-7.39(\mathrm{~m}, 9 \mathrm{H}) ;{ }^{13} \mathrm{C} \mathrm{NMR}(500 \mathrm{MHz}, \mathrm{CDCl} 3) \delta-3.0,-1.8,18.5,19.9,24.6$, $25.2,26.0,35.1,40.4,69.5,72.4,75.2,118.1(\mathrm{q}, \mathrm{J}=319 \mathrm{~Hz}), 121.1,127.2,127.45,127.5,127.8,128.3,128.4$, 131.2, 135.7, 138.5, 139.2, 148.2; IR (film) 3060, 3033, 1418, 1250, 1216, 1142, 1069, 897, 835, $772 \mathrm{~cm}^{-1}$; $\mathrm{MS}(\mathrm{Cl}) \mathrm{m} / \mathrm{z} 585.2284$ (585.2317 calcd for $\left.\mathrm{C}_{29 \mathrm{H}_{40}} \mathrm{~F} 3 \mathrm{O}_{5} \mathrm{SiS}, \mathrm{MH}\right), 527,470,347,345,225,213$; Anal. Calcd for $\mathrm{C}_{2} 9 \mathrm{H}_{3} \mathrm{~F}_{3} \mathrm{O}_{5} \mathrm{SiS} \mathrm{C}, 59.56 ; \mathrm{H}, 6.72$; Found: $\mathrm{C}, 59.45 ; \mathrm{H}, 6.67$. 
4aß-Benzyloxymethyl-10aß-tert-butyldimethylsilyloxy-1,2,4a,9,10,10a-hexahydrophenanthrene (22) and 4aß-Benzyloxymethyl-10aß-tert-butyldimethylsilyloxy-1,4,4a,9,10,10a-hexahydrophenanthrene (23). A mixture of 21 (42 mg, $0.072 \mathrm{mmol}), \operatorname{KOAc}(71 \mathrm{mg}, 0.72 \mathrm{mmol}), 10 \mathrm{~mol} \% \mathrm{Pd}(\mathrm{dppb})$ (prepared separately from $3.3 \mathrm{mg} \mathrm{Pd} 2(\mathrm{dba})_{3}$ and $3.4 \mathrm{mg}$ dppb in $0.2 \mathrm{~mL}$ of DMAC; color changed from violet to orange; catalyst was transferred with an additional $0.2 \mathrm{ml}$ of DMAC) in $0.4 \mathrm{~mL}$ DMAC in a sealed tube was purged three times with argon and then heated to $120^{\circ} \mathrm{C}$. After $30 \mathrm{~h}$ the reaction was nearly complete. Workup consisted of dilution with EtOAc, washing (1 N HCl, $\mathrm{H}_{2} \mathrm{O}$, brine), drying $\left(\mathrm{MgSO}_{4}\right)$ and filtration. After evaporation of the solvent, isolation by preparative TLC (silica gel, 50:1 hexane-ErOAc) gave $21 \mathrm{mg}(68 \%)$ of a mixture (>20:1 by ${ }^{1}$ H-NMR analysis) of 22 and 23 (99\% pure by GC analysis). A second fraction (2-3 mg) was a mixture of the reduction product $24(5-10 \%)$ and starting triflate 21 . The regioisomeric tricyclic products were separated by preparative TLC, when a $\sim 1: 1$-mixture was obtained with other catalysts (silica gel, 60:1 hexane-EtOAc, $2 x$ developed). Tricycle 22: higher $\mathrm{Rf}_{\mathrm{f}}{ }^{1} \mathrm{H} \mathrm{NMR}(500 \mathrm{MHz}, \mathrm{CDCl} 3) \delta 0.12$ (s, $\left.6 \mathrm{H}\right)$, $0.84(\mathrm{~s}, 9 \mathrm{H}), 1.72-1.88(\mathrm{~m}, 3 \mathrm{H}), 1.94(\mathrm{~m}, 1 \mathrm{H}), 2.18-2.32(\mathrm{~m}, 1 \mathrm{H}), 2.36-2.47(\mathrm{~m}, 1 \mathrm{H}), 2.80$ (ddd, $\mathrm{J}=6.5,9.5$, $16.6 \mathrm{~Hz}, 1 \mathrm{H}), 2.99(\mathrm{dt}, \mathrm{J}=5.6,17.0 \mathrm{~Hz}, 1 \mathrm{H}), 3.64(\mathrm{~d}, \mathrm{~J}=9.0 \mathrm{~Hz}, 1 \mathrm{H}), 3.82(\mathrm{~d}, \mathrm{~J}=9.0 \mathrm{~Hz}, 1 \mathrm{H}), 4.33(\mathrm{~d}, \mathrm{~J}=$ $12.4 \mathrm{~Hz}, 1 \mathrm{H}), 4.45(\mathrm{~d}, \mathrm{~J}=12.4 \mathrm{~Hz}, 1 \mathrm{H}), 5.67(\mathrm{dt}, \mathrm{J}=3.4,10.2 \mathrm{~Hz}, 1 \mathrm{H}), 5.89(\mathrm{dt}, \mathrm{J}=1.8,10.2 \mathrm{~Hz}, 1 \mathrm{H}), 7.05(\mathrm{~d}$, $\mathrm{J}=7.3 \mathrm{~Hz}, 1 \mathrm{H}), 7.08-7.18(\mathrm{~m}, 4 \mathrm{H}), 7.21-7.32(\mathrm{~m}, 3 \mathrm{H}), 7.48(\mathrm{~d}, \mathrm{~J}=7.6 \mathrm{~Hz}, 1 \mathrm{H}) ;{ }^{13} \mathrm{C} \mathrm{NMR}\left(125 \mathrm{MHz}, \mathrm{C}_{6} \mathrm{D}_{6}\right)$ $\delta-1.8,-1.5,19.0,23.0,26.3,27.6,31.9,33.9,47.9,73.4,75.0,77.6,125.7,125.8,126.1,127.35,127.4,128.4$, 128.6, 129.1, 131.7, 134.5, 139.3, 142.8; IR (film) 3064, 3028, 1255, 1117, 1099, 1083, 909, 834, 772, 733 $\mathrm{cm}^{-1}$; MS(CI) m/z 435.2685 (435.2719 calcd for $\left.\mathrm{C}_{28} \mathrm{H}_{39} \mathrm{O}_{2} \mathrm{Si}, \mathrm{MH}\right), 419,377,303,285,273,197,195,181$; Anal. Calcd for $\mathrm{C}_{28} \mathrm{H}_{38} \mathrm{O}_{2} \mathrm{Si}$ : C, 77.37; $\mathrm{H}, 8.81$; Found: $\mathrm{C}, 77.22 ; \mathrm{H}, 8.89$. Tricycle 23: lower $\mathrm{Rf}_{\mathrm{f}},{ }^{1} \mathrm{H}$ NMR $(500 \mathrm{MHz}, \mathrm{CDCl} 3) \delta 0.07(\mathrm{~s}, 3 \mathrm{H}), 0.09(\mathrm{~s}, 3 \mathrm{H}), 0.80(\mathrm{~s}, 9 \mathrm{H}), 1.91$ (ddd, J = 3.6, 9.2, $13.1 \mathrm{~Hz}, 1 \mathrm{H}), 2.08$ (m, $1 \mathrm{H}), 2.10-2.19(\mathrm{~m}, 2 \mathrm{H}), 2.47(\mathrm{~m}, 1 \mathrm{H}), 2.65(\mathrm{~m}, 1 \mathrm{H}), 2.89(\mathrm{~m}, 1 \mathrm{H}), 3.04(\mathrm{ddd}, \mathrm{J}=3.6,9.5,13.0 \mathrm{~Hz}, 1 \mathrm{H}), 3.58$ $(\mathrm{d}, \mathrm{J}=8.9 \mathrm{~Hz}, 1 \mathrm{H}), 3.70(\mathrm{~d}, \mathrm{~J}=8.9 \mathrm{~Hz}, 1 \mathrm{H}), 4.27(\mathrm{~d}, \mathrm{~J}=12.5 \mathrm{~Hz}, 1 \mathrm{H}), 4.35(\mathrm{~d}, \mathrm{~J}=12.5 \mathrm{~Hz}, 1 \mathrm{H}), 5.38(\mathrm{dd}, \mathrm{J}=$ $2.5,9.9 \mathrm{~Hz}, 1 \mathrm{H}), 5.66(\mathrm{dt}, \mathrm{J}=2.5,7.6 \mathrm{~Hz}, 1 \mathrm{H}), 7.06(\mathrm{~m}, 1 \mathrm{H}), 7.09-7.18(\mathrm{~m}, 4 \mathrm{H}), 7.20-7.36(\mathrm{~m}, 3 \mathrm{H}), 7.47(\mathrm{~m}$, $1 \mathrm{H}) ;{ }^{13} \mathrm{C}$ NMR $\left(125 \mathrm{MHz} \mathrm{CDCl}_{3}\right) \delta-2.4,-2.0,18.4,25.8,26.7,29.4,31.8,36.5,46.1,73.2,74.6,75.4$, 124.0. 125.0, 125.1, 125.8, 126.9, 127.07, 127.1, 128.1, 128.5. 135.3, 139.0, 141.1; IR (film) 3064, 3028 ,

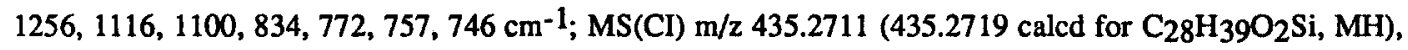
$419,377,303,285,197,195,181,157$; Anal. Calcd for $\mathrm{C}_{28} \mathrm{H}_{38} \mathrm{O}_{2} \mathrm{Si}$ : C, 77.37; H, 8.81; Found: C, 77.12; $\mathrm{H}$, 8.88 .

10aß-tert-butyldimethylsilyloxy-4aß-hydroxymethyl-1,2,3,4,4a,9,10,10a-octahydrophenanthrene (26). A 1:1.2 mixture of 22 and $23\left(58 \mathrm{mg}, 0.133 \mathrm{mmol}\right.$ ) was treated in $\mathrm{MeOH}$ (1.3 mL) with $\mathrm{H}_{2}$ (balloon) and $10 \%$ Pd-C (7 mg). After stirring overnight at $23{ }^{\circ} \mathrm{C}$, a single peak was observed by $\mathrm{GC}$ analysis. Removal of the catalyst by filtration and concentration gave $41 \mathrm{mg}(89 \%)$ of 26 as a colorless oil: ${ }^{1} \mathrm{H}$ NMR $\left(500 \mathrm{MHz}, \mathrm{CDCl}_{3}\right) \delta 0.20(\mathrm{~s}, 3 \mathrm{H}), 0.22(\mathrm{~s}, 3 \mathrm{H}), 0.97(\mathrm{~s}, 9 \mathrm{H}), 1.21(\mathrm{~m}, 1 \mathrm{H}), 1.37(\mathrm{~m}, 1 \mathrm{H}), 1.54(\mathrm{~m}, 3 \mathrm{H}), 1.72-$ $1.87(\mathrm{~m}, 2 \mathrm{H}), 2.06(\mathrm{bd}, \mathrm{J}=14.3 \mathrm{~Hz}, 1 \mathrm{H}), 2.08(\mathrm{dt}, \mathrm{J}=2.9,13.6 \mathrm{~Hz}, 1 \mathrm{H}), 2.31(\mathrm{bs}, 1 \mathrm{H}), 2.48$ (dd, $\mathrm{J}=11.4,19.4$ $\mathrm{Hz}, 1 \mathrm{H}$ ), 2.91 (ddd, J = 7.3, 11.4, $18.0 \mathrm{~Hz}, 1 \mathrm{H}$ ), 2.99 (ddd, J = 1.5, 7.7, $18.0 \mathrm{~Hz}, 1 \mathrm{H}$ ), 3.58 (bd, J = 10.6 Hz, $1 \mathrm{H}), 3.78(\mathrm{~d}, \mathrm{~J}=11.4 \mathrm{~Hz}, 1 \mathrm{H}), 7.10(\mathrm{~d}, \mathrm{~J}=7.3 \mathrm{~Hz}, 1 \mathrm{H}), 7.14(\mathrm{dt}, \mathrm{J}=1.5,7.3 \mathrm{~Hz}, 1 \mathrm{H}), 7.18(\mathrm{bt}, \mathrm{J}=7.0 \mathrm{~Hz}$, 1H), $7.31(\mathrm{~d}, \mathrm{~J}=7.3 \mathrm{~Hz}, 1 \mathrm{H}) ;{ }^{13} \mathrm{C} \mathrm{NMR}\left(125 \mathrm{MHz}^{\mathrm{C}} \mathrm{CDCl}_{3}\right) \delta-1.8,-1.3,18.7,21.35,21.4,26.3,27.7,32.7$, $33.9,47.6,70.8,78.4,125.99,126.02,126.7,129.2,135.8,139.0$; IR (film) $3450,3060,3016,1256,1057$, 
$1042,835,777,735 \mathrm{~cm}^{-1} ; \mathrm{MS}(\mathrm{Cl}) \mathrm{m} / 2347.2337$ (347.2406 calcd. for $\left.\mathrm{C}_{21} \mathrm{H}_{35} \mathrm{O}_{2} \mathrm{Si} \mathrm{MH}\right), 331,315,289,197$, $185,184,183,166,159$.

Acetal (27). A solution of silylether $26(37 \mathrm{mg}, 0.107 \mathrm{mmol})$, THF $(0.3 \mathrm{~mL})$ an $(n-B u) 4 N F(1 \mathrm{M}$ in $\mathrm{THF}, 0.16 \mathrm{~mL}, 1.5 \mathrm{eq}$ ) was maintained for $25 \mathrm{~min}$ at $23^{\circ} \mathrm{C}$, and after diluting with ErOAc, the organic layer was washed (saturated aqueous $\mathrm{NH}_{4} \mathrm{Cl}$, brine), dried $\left(\mathrm{MgSO}_{4}\right)$ ) and concentrated. This crude product then was dissolved in $\mathrm{CH}_{2} \mathrm{Cl}_{2}(0.4 \mathrm{~mL})$ and pyridine p-toluenesulfonate $(2.7 \mathrm{mg}, 0.011 \mathrm{mmol})$ and an excess of dimethoxypropane $(0.5 \mathrm{~mL}, 4.9 \mathrm{mmol})$ were added at $0^{\circ} \mathrm{C}$. After stirring at $23^{\circ} \mathrm{C}$ for $4 \mathrm{~h}$, EtOAc was added, the solution was washed (aqueous saturated $\mathrm{NaHCO}_{3}, \mathrm{H}_{2} \mathrm{O}$, brine) and the organic phase was dried $\left(\mathrm{MgSO}_{4} / \mathrm{K}_{2} \mathrm{CO}_{3}\right)$ and concentrated. Purification of the residue by flash chromatography (30:1 hexaneEtOAc, plus $0.2 \% \mathrm{NEt3}$ ) gave $23 \mathrm{mg}(79 \%)$ of 27 as a clear oil. Further filtration through a plug of silica gave a clear oil (22 mg, 76\%), which crystallized after several days (mp $\left.74-75^{\circ} \mathrm{C}\right):{ }^{1} \mathrm{H} \mathrm{NMR}\left(500 \mathrm{MHz}, \mathrm{C}_{6} \mathrm{D} 6\right) \delta$ $1.04(\mathrm{~m}, 1 \mathrm{H}), 1.30(\mathrm{~m}, 1 \mathrm{H}), 1.35(\mathrm{~s}, 3 \mathrm{H}), 1.42(\mathrm{~m}, 1 \mathrm{H}), 1.48-1.55(\mathrm{~m}, 2 \mathrm{H}), 1.59(\mathrm{~s}, 3 \mathrm{H}), 1.63(\mathrm{~m}, 1 \mathrm{H}), 1.76-$ $1.87(\mathrm{~m}, 2 \mathrm{H}), 2.32(\mathrm{~m}, 1 \mathrm{H}), 2.45(\mathrm{~m}, 1 \mathrm{H}), 2.71(\mathrm{~m}, 2 \mathrm{H}), 3.45(\mathrm{~d}, \mathrm{~J}=11.8 \mathrm{~Hz}, 1 \mathrm{H}), 3.82(\mathrm{~d}, \mathrm{~J}=11.8 \mathrm{~Hz}, 1 \mathrm{H})$, $6.96(\mathrm{~m}, 1 \mathrm{H}), 7.03(\mathrm{~m}, 2 \mathrm{H}), 7.10(\mathrm{~m}, 1 \mathrm{H}) ;{ }^{13} \mathrm{C} \mathrm{NMR}\left(125 \mathrm{MHz}, \mathrm{C}_{6} \mathrm{D}_{6}\right) \delta 22.3,22.5,26.8,28.4,31.2,31.8$, $34.6,40.2,67.9,74.5,98.0,126.2,126.5,126.8,128.3,129.6,136.3$; IR (film) 1378, 1367, 1254, 1245, 1205 ,

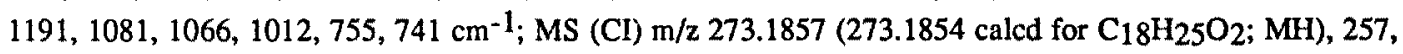
$215,214,197,185,184,131$.

\section{REFERENCES AND NOTES}

1. (a) DAAD NATO Postdoctoral Fellow, 1990-1992; current address: Organisch-Chemisches Institut, Universität Münster, Correnstr. 40, 4400 Münster/Westfalen, Germany. (b) Postdoctoral Fellow of the Alexander von Humboldt Foundation.

2. For reviews see: (a) Heck, R. F. Palladium Reagents in Organic Syntheses; Academic Press: London, 1985. (b) Trost, B. M.; Verhoeven, T. R. In Comprehensive Organometallic Chemistry; Wilkinson, G; Ed.; Pergamon Press: New York, 1982; Vol. 8, pp 867-874. (c) Heck, R. F. Org. React. 1982, 27, 345.

3. (a) Overman, L. E.; Abelman, M. M.; Kucera, D. J.; Tran, V. D.; Ricca, D. J. Pure Appl. Chem. 1992, 64, 1813. (b) Harris, G. D., Jr.; Herr, R. J.; Weinreb, S. M. J. Org. Chem. 1992, 57, 2528. (c) Trost, B. M.; Shi, Y. J. Am. Chem. Soc. 1991, 113, 701. (d) Zhang, Y.; Wu, G.; Agnel, G.; Negishi, E. J. Am. Chem. Soc. 1990, 112, 8590. (e) Grigg, R.; Loganathan, V.; Sukirthalingam, S.; Sridharan, V. Tetrahedron Lett. 1990, 31, 6573 .

4. (a) Abelman, M. M.; Overman, L. E; Tran, V. D. J. Am. Chem. Soc. 1990, 112, 6959. (b) Overman, L. E.; Ricca, D. J.; Tran, V. D. J. Am. Chem. Soc. 1993, 115, 2042. (c) Hong, C. Y.; Overman, L. E., Yagi, N. submitted for publication. (d) Rawal, V. H.; Michoud, C.; Monestel, R. F. J. Am. Chem. Soc. 1993, 115, 3030. (e) Chida, N.; Ohtsuka, M.; Ogawa, S. Tetrahedron Lett. 1991, 32, 4525. Hudlicky, T; Olivo, H. F. J. Am. Chem. Soc. 1992, 114, 9694. McIntosh, M. C.; Weinreb, S. M. J. Org. Chem. 1993, 58 , in press. (f) Ashimori, A.; Matsuura, T.; Overman, L. E. submitted for publication. (g) Comins, D. 
L.; Baevsky, M. F.; Hong, H. J. Am. Chem. Soc. 1992, 114, 10971. (h) McClure, K. F.; Danishefsky, S. J. J. Am. Chem. Soc. 1993, 115, 6094.

5. (a) Grigg, R.; Sridharan, V.; Stevenson, P.; Worakun, T. J. Chem. Soc., Chem. Commun. 1986, 1697. (b) Abelman, M. M.; Oh, T.; Overman, L. E. J. Org. Chem. 1987, 52, 4130.

6. For other recent examples and leading references, see: (a) Ashimori, A.; Overman, L. E. J. Org. Chem. 1992, 57, 4571. (b) Sato, Y.; Watanabe, S.; Shibasaki, M. Tetrahedron Lett. 1992, 33, 2589. (c) Sakamoto, T.; Kondo, Y.; Yamanaka, H. Tetrahedron Lett. 1992, 33, 6845. (d) Ozawa, F.; Kobatake, Y.; Hayashi, T. Tetrahedron Lett. 1993, 34, 2505.

7. (a) Daly, J. W.; Witkop, B.; Bommer, P.; Biemann, K. J. Am. Chem. Soc. 1965, 87, 124. (b) Daly, J. W.; Garraffo, M; Spande, T. F. The Alkaloids 1992, 43, 185.

8. (a) Fieser, L. F.; Fieser, M. Steroids; Reinhold: New York; 1959, Chapter 20. (b) Hamlyn, J. M.; Blaustein, M. P.; Bova, S. Proc. Natl. Acad. Sci. USA 1991, 88, 6259.

9. For a recent example of an intramolecular Heck reaction with substrates possessing an allylic alcohol moiety, see: Gaudin, J.-M. Tetrahedron Lett. 1991, 32, 6113.

10. De Jong, J. C.; Wildeman, J.; van Leusen, A. M.; Feringa, B. L. Synth. Commun. 1990, 20, 589.

11. Piers, E.; Grierson, J. R. J. Org. Chem. 1977, 42, 3755.

12. McMurry, J. E.; Scott, W. J. Tetrahedron Lett. 1983, 24, 979.

13. The authors have deposited atomic coordinates for this structure with the Cambridge Crystallographic Data Centre.

14. (a) Brown, M.; Piskiewicz, L. W. J. Org. Chem. 1967, 32, 2013. (b) Ireland, R. E.; Bey, P. Org. Synth. $1973,53,63$.

15. Smith, A. B., III; Branca, S. J.; Pilla, N. N.; Guaciaro, M. A. J. Org. Chem. 1982, 47, 1855.

16. (a) Suzuki, A. Pure Appl. Chem. 1991,63, 419. (b) Miyaura, N. Ishiyama, T.; Ishikawa, M. Suzuki, A. Tetrahedron Lett. 1986, 27, 6369. (c) Oh-e, T; Miyaura, N.; Suzuki, A. Chem. Lett. 1990, 221.

17. (a) Evans, D. A.; Gage, J. R.; Leighton, J. L. J. Am. Chem. Soc. 1992, 114, 9434. (b) Brown, H. C.; Racherla, U. S. Tetrahedron Lett. 1985, 26, 2187.

18. $\mathrm{dppb}=1,2$-bis(diphenylphosphino)butane; $\mathrm{TBDMS}=t$-butyldimethylsilyl; $\mathrm{Tf}=\mathrm{SO}_{2} \mathrm{CF}_{3}$

19. Cabri, W.; Candiani, I.; DeBernardianis, S.; Francalanci, F.; Penco, S.; Santi, R. J. Org. Chem. 1991, 56, 5796.

20. Jefferey, T. Tetrahedron Lett. 1991, 32, 2121.

\section{Acknowledgment}

Support of this investigation by PHS Grant GM-30859 is gratefully acknowledged. NMR and mass spectra were determined at UCI with instruments purchased with the assistance of NSF Shared Instrumentation Grants.

(Received 24 August 1993) 